\title{
Pandangan Orang Tua Tentang Pembelajaran Daring Untuk Anak Usia Dini
}

\author{
Diana Sahara Nofrika ${ }^{1 凶}$, Dadan Suryana $^{2}$ \\ Pendidikan Anak Usia Dini Fakultas IImu Pendidikan, Universitas Negeri Padang
}

$\triangle$ Corresponding author

(diananofrika@gmail.com)

\begin{abstract}
Abstrak
Orang tua dan guru memang harus berkerja sama dalam membantu anak untuk mengerjakan tugas di rumah apalagi anak usia dini yang mempunyai rasa bosan yang sangat tinggi dan tidak sabar dalam melakukan pekerjaan atau tugas dari guru Peran orang tua memiliki hal yang sangat penting dalam membantu guru yang sedang brjuang memenuhi pembelajaran yang harus di berikan kepada anak Sehingga dalam proses pembelajaran yang dilakukan secara daring ini, semua elemen pendidikan diminta untuk mampu dalam memberikan fasilitas-fasilitas pembelajaran agar tetap aktif walaupun dilakukan tanpa tatap muka secara langsung, Orang tua dituntut mampu membimbing anak belajar dari rumah dan mampu menggantikan guru disekolah, sehingga peran orang tua dalam tercapainya tujuan pembelajaran daring dan membimbing anak selama belajar dirumah menjadi sangat penting. Keuntungan dalam pembelajaran jarak jauh ini adalahkurang budgetuntuk biaya transportasi dari rumah ke sekolah (low cost), waktu pembelajaran tidak kaku sehingga dapat berkomunikasi dan belajar kapan saja dengan guru, pembelajaran jarak jauh tidak membatasi ruang jarak, siswa dapat mengakses pembelajarandari sumber yang sama, dan aksessiswayang luas sertatidak dibatasi oleh lokasi, Penelitian menggunakan metode studi pustaka yaitu dalam melakukan penelitian dilakukan dengan mengumpulkan informasi-informasi dan data dengan berbagai bantuan dari materi yang diperoleh seperti buku referensi, hasil penelitian seseorang yang sejenis, catatan, artikel dan berbagai macam jurnal lainya yang berkaitan dengan masalah yang di angkat yang ingin diselesaikan. Jadi metode penelitian ini menggunakan metode pustaka atau riteratur karena agar mudah untuk mencari atau menggali informasi tentang pandangan orang tua tentang pembelajaran daring untuk anak usia dini dan metode ini mampu menolong meneliti banyak hal yang di dapat dari artikel, buku-buku dan dokumen-dokumen yang terkait.
\end{abstract}

Kata Kunci: Pandangan Orang Tua, Pembelajaran Daring

\begin{abstract}
Parents and teachers do have to work together in helping children to do assignments at home, especially young children who have a very high boredom and are impatient in doing the work or assignments from the teacher. The role of parents is very important in helping teachers who are struggling to fulfill the learning that must be given to children So that in this online learning process, all elements of education are asked to be able to provide learning facilities so that they remain active even though it is done without face to face, parents are required to be able to guide children to learn from home and able to replace teachers at school, so the role of parents in achieving online learning goals and guiding children while studying at home is very important. The advantages of distance learning are that there is less budget for transportation costs from home to school (low cost), the learning time is not rigid so that they can communicate and learn anytime with the teacher, distance learning does not limit the distance space, students can access learning from the same source, and broad student access and not limited by location, Research uses the literature study method, namely in conducting research carried out by collecting information and data with various assistance from materials obtained such as reference books, research results of someone of the same kind, notes, articles and various other journals that related to the problem raised to be solved. So this research method uses the library or literature method because to make it easy to find or dig up information about parents' views on online learning for early childhood and this method is able to help research many things that can be obtained from articles, books and documents published related.
\end{abstract}

Keywords: Parents' Views, About Online Learning 


\section{PENDAHULUAN}

Pada masa pandemi saat sekarang orang tua dan guru memiliki tugas yang sangat exstra dalam pendidikan anak usia dini, pendidikan masa pandemi memang begitu jauh berbeda dengan pada masa-masa sebelum pandemi ada. Saat pandemi sekarang banyak gaya hidup yang berubah seperti cara belajar anak didik, cara pemberian pembelajaran dari guru untuk peserta didik dan model kehidup masyarakat. Kehidupan pada masa pandemi memiliki peraturan dari pemerintah yang wajib di ikuti oleh masyarakat. Kehidupan di masa pandemi semua masyarakat di wajibkan untuk tetap di rumah agar dapat membatasi penyebaran virus yang ada, dengan demikian semua kegiatan dilakukan di rumah dan tidak terkecuali sekolah yang dilakukan di rumah secara online yang disebut daring. Dengan berahlinya sekolah offline ke daring membuat sebagian besar orang tua memahami tentang tugas anak yang diberikan oleh guru. Orang tua dan guru memang harus berkerja sama dalam membantu anak untuk mengerjakan tugas di rumah apalagi anak usia dini yang mempunyai rasa bosan yang sangat tinggi dan tidak sabar dalam melakukan pekerjaan atau tugas dari guru. Peran orang tua memiliki hal yang sangat penting dalam membantu guru yang sedang brjuang memenuhi pembelajaran yang harus di berikan kepada anak. Karena anak usia dini adalah masa keemasan menurut pendapat Salah satu periode yang menjadi penciri masa usia dini adalalah periode keemasan. Namun disisi lain anak usia dini berbeda pada masa kritis, yaitu masa keemasan anak tidak akan dapat diulang kembali pada masa-masa berikutnya, jika potensi-potensinya tidak distimulasi secara optimal dan maksimal pada usia dini tersebut. Dampak dari tidak terstimulasinya berbagai potensi saat usia emas, akan menghambat terhadap perkembangan anak berikutnya, Suryana (2013:25).

Pendidikan anak usia dini pada dasarnya meliputi seluruh upaya dan tindakan yang dilakukan oleh pendidik dan orangtua dalam proses perawatan, pengasuhan dan pendidikan pada anak dengan menciptakan aura dan lingkungan dimana anak dapat mengeksplorasi pengalaman yang memberikan kesempatan kepadanya untuk mengetahui dan memahami pengalaman belajar yang diperolehnya dari lingkungan(Suryana \& Rizka,2019).Pada masa pembelajaran daring yang ditetapkan pemerintah, ditujukan kepada seluruh jenjang pendidikan dari TK hingga perguruan tinggi. Dipilihnya alternatifini dikarenakan berkembangnya revolusi industri4.0. Berkembangnya revolusi industri sangat mendukung terlaksananya pembelajaran daring dari rumah, karena pembelajaran daring adalah pembelajaran yang mengeliminasi waktu dan jarak dengan bantuan platformdigital berbasis internet yangmampu menunjang pembelajaran untuk dilakukan tanpa adanya interaksi fisik antara pendidik dan peserta didik (Putra\& Irwansyah, 2020), sehingga kecanggihan teknologi jaman sekarang diharapkan mampu menunjang kegiatan daring tersebut. Namun pada jenjang pendidikan TK, pembelajaran daring memerlukan keterlibatan orang tua langsung dalam pelaksanaannya. Selama pandemi Covid-19 berlangsung, pembelajaran secara daring telah dilakukan hampir diseluruh penjuru dunia, namun sejauh ini pembelajaran dengan sistem daring belum pernahdilakukan secara serentak (Sun et al., 2020). Sehingga dalam proses pembelajaran yang dilakukan secara daring ini, semua elemen pendidikan diminta untuk mampu dalam memberikan fasilitas-fasilitas pembelajaran agar tetap aktif walaupun dilakukan tanpa tatap muka secara langsung. Orang tua dituntut mampu membimbing anak belajar dari rumah dan mampu menggantikan guru disekolah, sehingga peran orang tua dalam tercapainya tujuan pembelajaran daring dan membimbing anak selama belajar dirumah menjadi sangat penting.

Pada akhir tahun 2019 penularan Covid-19 merebak dengan sangatcepat dan masif. Untuk mencegah penularan dari orang ke orang secara intensif, maka pemerintah mengeluarkan kebijakan untuk melaksanakan seluruh kegiatan di rumah saja untuk memutuskan mata rantai penyebaran Covid-19. Pembelajaran jarak jauh dilaksanakan dimulai dari tingkat PAUD hingga perguruan tinggi (Mendikbud, 2020). Transformasi pembelajaran pendidikan anak usia dini, biasanya konvensional menjadi berbasis teknologi dan dilakukan secara massal. Pembelajaran jarak jauh ini, sebenarnya bukan fenomena baru pada pendidikan di Indonesia. Pada perguruan tinggi, Universitas Terbuka terbiasa menerapkan pembelajaran berbasis teknologi dan distance learning (Hariyati, 2006). Dalam keadaan belajar mengajar yang serba onlineini, memiliki kelebihan dan keterbatasannya sendiri. Keuntungan dalam pembelajaran jarak jauh ini adalah kurang budget untuk biaya transportasi dari rumah ke sekolah (low cost), waktu pembelajaran tidak kaku sehingga dapat berkomunikasi dan belajar kapan saja dengan guru, pembelajaran jarak jauh tidak membatasi ruang jarak, siswa dapat mengakses pembelajarandari sumber yang sama, dan aksessiswayang luas sertatidak dibatasi oleh lokasi.

\section{METODE PENELITIAN}

Penelitian menggunakan metode studi pustaka yaitu dalam melakukan penelitian dilakukan dengan mengumpulkan informasi-informasi dan data dengan berbagai bantuan dari materi yang diperoleh seperti buku referensi, hasil penelitian seseorang yang sejenis, catatan, artikel dan berbagai macam jurnal lainya yang berkaitan dengan masalah yang di angkat yang ingin diselesaikan. Menurut Zed. 2014:3 studi pustaka ialah studi literatur yang merupakan kegiatan berkenaan dengan metode pengumpulan data serta mengolah bahan penelitian. Dengan Sumber data yang di ambil dari berberapa buku, jurnal dan dokumen hasil penelitian 
sebelumnya yang relevan dengan penelitian ini. Selanjut nya pendapat yang dikemungka kan oleh Nazir. 2014:27 studi literatur yaitu pengolahan data dengan teknik pengumpulan data penelaahan terhadap bukubuku, literatur-literatur, catatan-catatan dan laporan-laporan yang ada hubungannya dengan masalah yang dipecahkan.

Jadi metode penelitian ini menggunakan metode pustaka atau riteratur karena agar mudah untuk mencari atau menggali informasi tentang Pengaruh hubungan keharmonisan orang tua dengan kemandirian anak dan metode ini mampu menolong meneliti banyak hal yang di dapat dari artikel, buku-buku dan dokumen-dokumen yang terkait.

\section{HASIL DAN PEMBAHASAN}

Peran orang tua sangat penting dalam perkembangan anak. Menurut Brooks (2011) bahwa pola asuh sangat terbukti berpengaruh dalam aspek-aspek perkembangan anak yang seperti aspek perkembangan anak, aspek perkembangan fisik, kognitif, dan sosial emosional. Jika pola asuh yang diberikan orang tua terhadap anak tidak tepat dapat mengakibatkan pribadi anak yang bermasalah saat anak dewasa nanti. (Hermawati, Susanti, \& Jamaludin, 2018). Dapat dilihat peran orang tua selama ini lebih cendrung dengan perawatan anak dan pengasuhan namun pendidikan akademik diberikan keseluruhannya kepada pihak sekolah dengan demikian pandangan orang tua terhadap sekolah daring beranggapan semua beban sekolah tidak beban orang tua padahal sekolah dan orang tua seharusnya berkerja sama dalam perkembangan anak tersebut. Diadha (2015) menjelaskan bahwa ternyata masih banyak orang tua yang lepas tangan terhadap kewajiban mendidik anak ketika mereka sudah memasukkan anak mereka ke lembaga pendidikan. Jadi peran oran orang tua sangat penting dalam perkembangan anak yang akan datang sebab anak dalam bimbingan orang tua dan anak lebih banyak menghabiskan waktu bersama keluarga atau orang tuanya.

Peran keluarga dalam pendidikan anak adalah hal terpenting dan pertama dalam kehidupan anak. (Hasbi, 2012). Diharapkan kepada Keluarga untuk dapat memenuhi segala kebutuhan anak agar anak mempunyai perkembangan yang sangat baik dan memberikan perawatan juga pendidikan yang terbaik. Dalam membentuk krakter anak, keluarga memupayakan dalam keluarga menciptakan hubungan atau suasana yang harmonis untuk membuat anak nyaman berada dalam lingkungan tersebut. (Gade, 2012). Hal tersebut dapat terjadi apabila adanya komunikasi yang baik dan berkesinambungan diantara orang tua dan anak.

Strategi orang tua mengajarkan dan membangun regulasi diri, kepada anak untuk mengembangkan perilaku yang dilepaskan guna memiliki kemampuan mengatur dan merencanakan proses belajarnya sendiri setiap hari di rumah,antara lain yang dapat dilakukan adalah, mendiskusikan tentang beberapa aturan di dalam rumah, memberikan arah kepada anak tentang perilaku yang sewajarnya, contohnya adalah agar anak mendapatkan panduan untuk mencapai prestasi, menyampaikan cara yang tidak rumit kepadaanak untuk memecahkan masalah yang berkaitan dengan kemampuan menjagahubungan interpersonal dengan guru danteman kelasnya selama di rumah, jika anak menunjukkan perilaku yang emosional, tunjukkan cara mengatasinya dan juga jelaskanlah akibat dari perilaku tersebut, jadilahsahabat atapunteman dalam berbagi tugas yang berkaitan dengan regulasi diri (contohnya sebagai teman berpikir dalam menyelesaikan tugas danmenjadi teman untuk bertanya), dan ini harus menjadi proses yang konsisten, mempersiapkan danmenunjukan strategi yang nyata kepada anak dalam usahamempertahankan kemampuan belajarnya (contohnya mempersiapkan dan menjadwalkan kegiatan belajar anak secara terperinci agar mudah diikuti), mempersiapkan petunjuk bagaimana sebaiknya belajar yang efektif (contohnyamemberi anak pertanyaanlalukemudian meminta anak untuk memberi jawaban secara lengkap dengan cara membaca bukubuku yang ada di rumah), berikanlah kesempatan kepada anak untuk mengerjakan tugas secara mandiriyang rumit dan tentu saja orang tua perlu mempersiapkan petunjuk yang dapat dijadikan acuan untukanak, terutama yang belum memiliki kemampuan untuk mengatur kegiatan belajar secara mandiri sebelumnya (Subarto, 2020).

Orang tua yang memiliki strategi yang matang dalam pembentukan perkembangan anak mereka yang mampu meluangkan waktu untuk anak di dalam sela waktu tuntutan perkerjaan yang sangat padat dan banyak, dalam perkembangan anak peran orang tua berpengaruh penting karena anak sering berhadapan bersama orang tua atau keluarga dan waktu yang lebih banyak bersama keluarga. di sekolaha anak hanya dibantu oleh guru dalam mengembangkan berberapa aspek yang akan dikembangkan selebih itu semua tergantung kelurga karena apabila keluarga mampu memberikan didikan yang baik anak akan berkembang dengan baik dan sebaliknya apabila orang tua memberikan didikan yang kurang anak juga akan terbentuk kurang baik dalam perkembangan nya.

Orangtua harus kreatif memberikan berbagai kegiatan yang positif untuk anakselama mereka di rumah. Namun, sebuah studi mengungkapkan bahwa hanya sekitar $0.9 \%$ dari 39 orangtua yang menyusun kegiatan bermain dan belajar untuk anak selama di rumah(Sari \& Maningtyas, 2020). Hal ini menunjukkan adanya keterbatasan dari orangtua untuk memberikan kegiatan yang terarah bagi anak sehingga dapat memunculkan rasa bosan dan terlewatnya proses stimulasi perkembangan. Di sisi lain, anak merasa bahwa 
SFH sama halnya dengan liburan sehingga mereka tidak mengerjakan apapun seeprti rutinitas ketika sekolah (Bhamani et al., 2020). Jadi menjadi peran orang tua memang dituntun banyak karena anak juga memiliki hak yang harus dipenuhi oleh orang tua karena anak harus memiliki masa depan yang baik dengan perkembangan yang sangat baik oleh karena itu orang tua memiliki tanggung jawab dalam segala tumbuh kembang anak. Dengan dampingan orang tua anak merasa memiliki dorongan yang kuat dalam belajar dimanapun berada setiap anak pasti memiliki suatu bentuk semanga yang tinggi jika orang tua dan keluarga mampu mendukungnya dalam berkembang untuk dirinya sendiri.

Orangtua membantu mengembangkan kemampuan anak dengan kegiatan bermain yang bisa mencakup berbagai kemampuan seperti motorik, kognitif, emosi dan kemampuan lainnya. Namun di masa pandemi COVID-19, tentu sangat terbatas. Selama pandemi COVID-19 dalam mendampingi anak belajar banyak kesulitan yang di hadapi salah satunya waktu. Selain menemani anak bermain, keterbatasan waktu juga dirasakan orangtua ketika mendampingi anak belajar online. Tidak hanya untuk orang tua yang bekerja, tetapi juga iburumah tangga mengatakan bahwa ada kesulitan tiap kali mendapingi anak belajar di rumah. Mereka harus membagi waktu dengan pekerjaan lain seperti urusan rumah tangga, kerja, anak lebih dari satu dan lainnya.

Hasil penelitian Luhung Kawuryaning Pertiwi, dkk (2021) menyatakan bahwa menyoroti kebutuhan untuk lebih memahami bagaimana seharusnya orang tua terlibat dan bekerjasama dengan guru agar anak tetap mendapatkan pembelajaran yang optimal di masa pandemi seperti ini. Guru dan orang tua membutuhkan komitmen dan komunikasi yang jelas antarsesama sehingga orang tua memahami capaian yang perlu dikembangkan oleh anak dan program sekolah pun tercapai dengan baik.

Penelitian dari Anita Wardani dan Yulia Ayriza (2021) menunjukkan bahwa secara umum kendalakendala orang tua dalam mendampingi anak belajar di rumah padamasa pandemi Covid-19 adalah kurangnya pemahaman materi oleh orang tua, kesulitan orang tua dalam menumbuhkan minatbelajar anak, tidak memiliki cukup waktuuntuk mendampingi anak karena harus bekerja, orang tua tidak sabar dalam mendampingi anak saat belajar dirumah, kesulitan orang tua dalam mengoperasikan gadget, dan kendala terkait jangkauan layanan internet.

Jadi umumnya pandangan orang tua terhadap belajar daring mempunyai pengaruh yang sangat besar karena banyak kendala-kendala yang dimiliki oleh orang tua tersebut baik dalam segi waktu yang padat dan pemahaman orang tua terhadap pembelajaran daring atau belajar dirumah.

Penelitian dari Mega Ria Agustina, dkk (2021) ada berberapa gambaran yang di dapat dalam penelitian ini yaitu: 1) gambaran pola asuh orang tua di rumah, 2) gambaran komunikasi orang tua dengan anak dan guru, 3) upaya orangtua dalam mendampingi anak belajar, 4) gambaran sikap orang tua dalam pengambilan keputusan, dan 5) gambaran kerjasama orang tua, anak dan guru. Hasil penelitian ini dapat menjadi pandangan bagi orangtua ketika mendampingi anak belajar di rumah selama pandemi.

Hasil Penelitian (Agustin, Puspita, Nurinten, \& Nafiqoh, 2020)juga memaparkan bahwa terdapat beberapa yang menunjukkan adanya keterbatasan atau kekurangan dari penerapan pembelajaran jarak jauhsecara online yang membuat anak menjadi bosan karena tidak bertemu secara langsung bersama teman dan anak akan lebih sering menatap layar handphone atau laptop yang dapat membuat kesehatan mata anak terganggu. Selain itu, dalam penggunaan internet yang harus dikeluarkan setiap anak akan membuat tagihan tambahan bagi orang tua dalam penyediaan layanan internet di rumah dan kondisi sinyal yang mendukung. Jadi dapat disimpulkan bahwa belajar daring menemukan banyak kendala yang begitu banyak seperti dengan anak yang mudah bosan belajar di rumah karena taka da teman yang sebaya, orang tua yang mengeluarkan uang beli paket untuk internet dan waktu yang harus di bagi oleh orang tua dikala perkerjaan yang sangat padat.

\section{SIMPULAN}

Peran orang tua sangat penting dalam perkembangan anak Orang tua yang memiliki strategi yang matang dalam pembentukan perkembangan anak mereka yang mampu meluangkan waktu untuk anak di dalam sela waktu tuntutan perkerjaan yang sangat padat dan banyak, dalam perkembangan anak peran orang tua berpengaruh penting karena anak sering berhadapan bersama orang tua atau keluarga dan waktu yang lebih banyak bersama keluarga. di sekolaha anak hanya dibantu oleh guru dalam mengembangkan berberapa aspek yang akan dikembangkan selebih itu semua tergantung kelurga karena apabila keluarga mampu memberikan didikan yang baik anak akan berkembang dengan baik dan sebaliknya apabila orang tua memberikan didikan yang kurang anak juga akan terbentuk kurang baik dalam perkembangan nya Dengan dampingan orang tua anak merasa memiliki dorongan yang kuat dalam belajar dimanapun berada setiap anak pasti memiliki suatu bentuk semanga yang tinggi jika orang tua dan keluarga mampu mendukungnya dalam berkembang untuk dirinya sendiri 


\section{UCAPAN TERIMA KASIH}

Terima kasih penulis ucapkan kepada dosen pengampu mata kuliah Manajement Pendidikan Anak Usia Dini yang telah memotivasi penulis untuk menyelesaikan penelitian ini, keluarga tercinta dan semua pihak yang telah membantu selesainya penelitian ini.

\section{DAFTAR PUSTAKA}

[1] Anita Wardani \& Yulia Ayriza (2021). Analisis Kendala Orang Tua dalam Mendampingi Anak Belajar di Rumah PadaMasa Pandemi Covid-19. Volume 5 Issue 1 (2021) Pages 772-782

[2] Agustin, M., Puspita, R. D., Nurinten, D., \& Nafiqoh, H. (2020). Tipikal kendala guru PAUD dalam mengajar pada masa pandemi Covid-19 dan implikasinya. Jurnal Obsesi, 5 (1), 334 -345.doi: 10.31004/obsesi.v5i1.598.

[3] Brooks, J. (2011). The Process of Parenting. Yogyakarta: Pustaka Pelajar.

[4] Bhamani, S., Makhdoom, A. Z., Bharuchi, V., Ali, N., Kaleem, S., \& Ahmed, D. (2020). Home Learning in Times of COVID: Experiences of Parents. Journal of Education and Educational Development, 7(1), 9. https://doi.org/10.22555/joeed.v7i1.3260

[5] Hermawati, R., Susanti, N., \& Jamaludin. (2018). Penyuluhan pendidikan karakter bagi anak-anak Desa Bojong Menteng Banten. Jurnal Pengabdian Dharma Laksana, 1(1), 91-100.

[6] Diadha, R. (2015). Keterlibatan orang tua dalam Pendidikan Anak Usia Dini di Taman Kanak-kanak. Edusentris, 2(1), 61-71.

[7] Gade, F. (2012). Ibu sebagai madrasah dalam pendidikan anak. JURNAL ILMIAH DIDAKTIKA: Media IImiah Pendidikan dan Pengajaran, 13(1), 31-40.

[8] Luhung Kawuryaning Pertiwi, Dkk (2021). Keterlibatan Orang Tua Terhadap Pembelajaran Daring Anak Usia Dini Pada Masa Pandemi Covid-19. Vol. 12. No.1 Mei 2021 | Hal 19-30

[9] Putra, R., \&lrwansyah, I. (2020). Media Komunikasi Digital, Efektif namun Tidak Efisien, Studi Media Richness Theory dalam Pembelajran Jarak Jauh Berbasis Teknologi di Masa Pandemi. Jurnal IImu Sosial dan Politik, 1(2), 1-13.

[10] Sun, L., Tang, Y., \& Zuo, w. (2020). Corona Virus Pushes Education Online. Nature Materials, 687-687. Doi: https://doi.org/10.1038/s41563-202-0678-8.

[11] Subarto. (2020). Momentum Keluarga Mengembangkan Kemampuan Belajar Peserta Didik Di Tengah

Wabah Pandemi Covid-19. Universitas Pamulang, DOI: 10.15408/41i.15838. 